\title{
Cross-sectional study about primary health care professionals views on the inclusion of the vaccine against human papillomavirus in the vaccine schedules
}

M. Reyes Oliver Pérez , Victoria Bravo Violeta ${ }^{1}$, Ana Vazquez del Campo ${ }^{2}$, Cristina Ruiz², Sonia Yáñez Castaño², Laura P. Pérez Conde ${ }^{2}$ and Jesús S. Jiménez López ${ }^{1 *}$

\begin{abstract}
Background: Although the inclusion of the HPV vaccine has been registered in Spain since 2007, vaccination rates are lower than expected. The patients wish to be vaccinated is heavily influenced by information they have received from many source. The Knowledge of primary health care professionals affects the information provided to patients and is fundamental in the decision making. The aim of this study is to assess the opinions of primary health care professionals on the vaccine against HPV and their knowledge about HPV infection and its links to with gynecological and oropharyngeal cancer.

Methods: Cross-sectional study. A 19-item survey was drawn up. It included questions on basic aspects of HPV infection and marketed vaccines, personal opinion about the inclusion in the immunization schedules and their level of prescription and recommendation to patients in their clinical practice. From October 2013 to December 2013, 607 surveys were distributed among 20 primary health centers affiliated to the University Hospital 12 de Octubre. The results were analyzed using SPSS statistical package.

Results: One hundred sixty four successfully completed surveys were obtained for analysis. $89 \%$ of the professionals knew about the relationship between HPV infection and cervical cancer, $57.3 \%$ did not know any of the serotypes against which vaccines are targeted; $40.4 \%$ believed that there is insufficient data to support the commercialization of the vaccines. Of these, $65.7 \%$ argue that there is no data of its long-term effectiveness, $13.4 \%$ that there is no data as to its side effects, $13.4 \%$ believed that the cost effectiveness is not worthwhile.

Conclusions: There is a strong controversy among health professionals regarding the marketing and inclusion of HPV vaccine in immunization schedules. However, the knowledge of the primary care health professionals on key aspects of infection and vaccine protection are insufficient. The training of professionals in vaccination, cervical pathology and HPV infection should be improved to provide objective information on the use as this vaccine for patients.
\end{abstract}

Keywords: Human papilloma virus, HPV vaccines, Cervical cancer, Primary care

\footnotetext{
* Correspondence: jjimenez.hdoc@salud.madrid.org

1 Department of Gynecologic Oncology, Hospital Universitario 12 de Octubre,

Avda Cordoba s/n, Madrid, Spain

Full list of author information is available at the end of the article
} 


\section{Background}

Human papilloma virus (HPV) infection is the most common sexual transmitted disease worldwide. The overall prevalence of the infection in Spain is $14.3 \%$ (95\% Confidence interval (CI): 13.1 to 15.5), $28.8 \%$ (95\% CI: 26.6 to 31, 1) in women between 18 and 25 [1]. HPV infection is considered the most important risk factor for developing cervical cancer [2]. The most frequently isolated genotypes in both malignant and premalignant disease are HPV 16 and 18, followed by 45 and $31[3,4]$.

Since 2006, two prophylactic HPV vaccines have been available in Spain: Gardasil ${ }^{\circ}$ (Merck \& Co., Whitehouse Station, NJ USA) and Cervarix ${ }^{\circ}$ (GlaxoSmithKline Biologicals, Rixensart, Belgium). They consist of the native virus-like particles (VLPs), which are morphologically and immunogenetically similar to virions, but lack infectivity, replicative and tumorigenicity.

Both vaccines have demonstrated a high level of effectiveness against genotypes 16 and 18 [5, 6]. Cervarix ${ }^{\bullet}$ contains VLPs genotypes 16 and 18. It has been proved to be safe to administer in women up to 55 and has proved to generate protection for nonvaccine genotypes 31 and 45 [7]. Gardasil ${ }^{\circ}$ contains VLPs genotypes $6,11,16$ and 18 . It has been also proven to be safe to administer in women up to 45 and in males.

United States, Australia, Canada and the UK were the first countries to introduce HPV vaccination into their routine immunization programs. In February 2007 Spain agreed to include the vaccine in the immunization schedules for girls between 11-14. Furthermore, it was agreed to recommend vaccination for all women up to age 26 and individualized assessment of vaccination in women over 26 years old and in males 9-26 years old out of public funding.

However, rates of vaccination in Spanish women have been lower than expected [8]. The controversy of the benefits of vaccination and its relation to possible adverse reactions, and the existence of groups of health care professionals with contrary opinions to the vaccine implementation, could play an important role in the low consumption of the vaccine. The more information we give to the patients, the higher the acceptance of the vaccine will be $[9,10]$. The primary health care professionals (PHCP) are the first stage to transmiting information and opinion to patients.

The main objective of this study is to asses the opinions of PHCP of primary care centers affiliated to the Hospital 12 de Octubre (Madrid) on the vaccine against HPV and their knowledge about its characteristics and indications, and the basics concepts of HPV infection and its links to with gynecological and oropharyngeal cancers.

\section{Material and methods}

Cross-sectional study. The research was conducted in 20 primary health centers attached to the Hospital 12 de Octubre.

To obtain the data, we drew up a survey consisting of nineteen questions, 5 of open question format and 14 of multiple choice questions. The survey is divided in four sections (Fig. 1):

- Section I: Socio-demographic data, such as sex, age and occupation.

- Section II: Knowledge of basics concepts of HPV infection and vaccines marketed

- Section III: Personal opinion about the vaccine and its inclusion in the immunization schedules.

- Section IV: Prescribing and recommending the vaccine.

To design the survey, a literature review in databases the PubMed-Medline and UPTODATE was carried out. The keywords used were: Human papillomavirus, Vaccination, Cervical cancer.

The survey was aimed at PCHPs. Primary care physicians; primary care pediatricians and primary care nurses have been considered as PCHPs. Gynecologists have been excluded from the study because they are not the first stage to transmitting information and opinion on the primary prevention strategies to patients in our public health system.

The collected variables were included in an Excel database. Statistical analysis was performed with SPSS, version 15.0. Incomplete Surveys were not taken into account. We used the chi-square test to assess the significance of the association between two categorical variables. Statistical significance was considered as $p<0.05$.

\section{Results}

From October 2013 to December 2013, 607 surveys were delivered to 20 primary health centers attached to the Hospital 12 de Octubre; Of them, 171 were completed and 164 of these were valid for the analysis. The participation rate is $28 \%$. The percentage of men among those who replied was 25 and $65.2 \%$ of women. The average age of participants was 46.6 years $(\mathrm{SD} \pm 9.2$, range 23-64) (Table 1).

\section{Section II: Knowledge of basics concepts of HPV infection and vaccines marketed}

A total of 101 (61.6\%) of participants didn't know any of the genotypes against which the bivalent vaccine (HPV 16 and 18) protects. The 60.4\% (99) of participants didn't know any of the genotypes against which the quadrivalent vaccine protects (HPV 16,18,11,6). If we combine the above data, we find that $57.3 \%$ (94) of 


\begin{tabular}{|c|c|c|c|c|}
\hline \multicolumn{5}{|c|}{ SECTION I: SOCIODEMOGRAPHIC DATA } \\
\hline 1. & \multirow{2}{*}{\multicolumn{4}{|c|}{ Survey Date }} \\
\hline 2. & \multirow{2}{*}{\multicolumn{4}{|c|}{ Date of birth: }} \\
\hline \multirow[t]{3}{*}{3.} & & \multirow{3}{*}{\multicolumn{3}{|c|}{$\begin{array}{l}\text { Man } \\
\text { Woman }\end{array}$}} \\
\hline & $\circ$ & & & \\
\hline & $\begin{array}{r}\circ \\
\text { Profess }\end{array}$ & & & \\
\hline & Profess & & & \\
\hline & $\stackrel{\circ}{\circ}$ & $\begin{array}{l}\text { Nurse } \\
\text { Primary Care Professional (PCP) }\end{array}$ & & \\
\hline & 。 & Pediatrician & & \\
\hline 5. & Starting & late of profesional activity: & & \\
\hline & SECTIO & II: KNOWLEDGE OF BASICS CONCEPS OF HPV INFECTION AND VACCINES MARKET & & \\
\hline 6. & HPV va & ine contains particles similar to virus type (Open question): & & \\
\hline & $\circ$ & 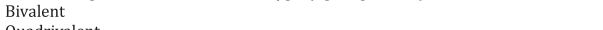 & & \\
\hline 7. & $\frac{0}{\text { List the }}$ & $\begin{array}{l}\text { Quadrivalent } \\
\text { ancers associated with HPV infection (Open question) }\end{array}$ & & \\
\hline 8. & Age ran & of top priority of the vaccine (Open question) & & \\
\hline 9. & Age ran & of high priority of the vaccine (Open question) & & \\
\hline 10. & Maximt & 1 age for bivalent and quuadrivalent vaccine (Open question) & & \\
\hline & & & $\mathrm{n}$ & $(\%)$ \\
\hline 11. & $\begin{array}{l}\text { Regard } \\
\circ \text { The }\end{array}$ & $\begin{array}{l}\text { g to the effectiveness of the vaccine, mark the correct answer: } \\
\text { accine has proven to decrease the incidence of cervical cáncer. }\end{array}$ & & \\
\hline & $\circ \mathrm{TH}$ & raccine has proven to decrease the incidence of premalignant lesions (CIN 2/3) & 16 & 9.8 \\
\hline & $\circ$ Th & vaccine has proven to increase the amount of circulating HPV antibodies & $\begin{array}{c}16 \\
104\end{array}$ & $\begin{array}{l}9.8 \\
63.4\end{array}$ \\
\hline & $\circ$ The & $\begin{array}{l}\text { accine has not proven to be effective in the clinical trials. } \\
\text { ans }\end{array}$ & 11 & 6.7 \\
\hline & Mark t & main source from which you has obtained the information of HPV vaccine: & & \\
\hline & $\circ$ & Congress. & & \\
\hline & $\circ$ & Laboratories & 44 & 26.8 \\
\hline & 。 & Medical Journals & 54 & 32.9 \\
\hline & $\circ$ & Training seminars at the health center & 74 & 45.1 \\
\hline & 。 & Other colleagues. & 63 & 38.4 \\
\hline & & Communication media (TV, Internet, radio...) & 44 & 26.8 \\
\hline & & & 12 & 7.3 \\
\hline & SECTIO & III: PERSONAL OPINION ABOUT THE VACCINE & & \\
\hline 13. & $\begin{array}{l}\text { Do you } \\
\text { vaccine }\end{array}$ & consider that there is enough data to support the commercialization of the & 96 & 596 \\
\hline & $\circ$ & Yes & 65 & 40.4 \\
\hline & 。 & No & & \\
\hline 14. & If you & ve answered No to the above question, mark the option that you consider is & & \\
\hline & conside & 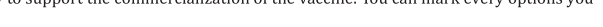 & 108 & 65.7 \\
\hline & $\circ$ & Long term effectiveness. & 22 & 13.4 \\
\hline & $\circ$ & Long term risk. & 17 & 10.4 \\
\hline & $\circ$ & Cost effectiveness & 7 & 4.5 \\
\hline & $\circ$ & The possible need for revaccination. & 10 & 6 \\
\hline & o & The replace of ecological niche for other carcinogenic HPV types & & \\
\hline & In your & pinión, What is the most important factor in the commercialization of the vaccine? & & \\
\hline & $\circ$ & Effectiveness and risk data & 87 & 53 \\
\hline & $\circ$ & The interests of the pharmaceutical industry & 49 & 30 \\
\hline & 。 & Political factors & 17 & 16 \\
\hline & $\circ$ & Luucrative interest of some health care professionals & 11 & 0.6 \\
\hline 16. & $\begin{array}{l}\text { Do you } \\
\text { are app }\end{array}$ & $\begin{array}{l}\text { onsider that the current indications of the vaccine in the publicly health system } \\
\text { piate?: }\end{array}$ & 68 & 40.4 \\
\hline & 0 & Yes & 96 & 59.6 \\
\hline & $\circ$ & No & & \\
\hline 17. & $\begin{array}{l}\text { If you } \\
\text { innapro }\end{array}$ & $\begin{array}{l}\text { nswered No to the above question, Why do you think the indications are } \\
\text { iate? You can mark every options you consider: }\end{array}$ & & \\
\hline & $\circ$ & Economics factors & 40 & 24.4 \\
\hline & $\circ$ & Insufficient coverage regarding age range & 53 & 32.3 \\
\hline & $\circ$ & Insufficient coverage regarding the sex & 43 & 26.2 \\
\hline & $\circ$ & It can generate disregard for other STDs & 28 & 17.1 \\
\hline 18. & Do you & onsider that the health care professionals disagree with the inclusión of the & & \\
\hline & 0 & Yes & 50 & 28.7 \\
\hline & ○ & No & 114 & 71.3 \\
\hline 19. & If you a & swered Yes to the above question, what do you think about? You can mark every & & \\
\hline & options & ou consider: & 54 & 50 \\
\hline & $\circ$ & A minority disagrees & 31 & 28.7 \\
\hline & $\circ$ & Both positions are balanced & 23 & 21.3 \\
\hline & $\circ$ & A majority disagrees & & \\
\hline & BLOQU & V: PRESCRIPCION Y RECOMIENDACIÓN & & \\
\hline 20. & In your & xperience in clinic, the percentaje of women of 15 and 50 years old who ask about & & \\
\hline & $\begin{array}{l}\text { the vac } \\
0\end{array}$ & he is: & 7 & 3.9 \\
\hline & 。 & $50-75 \%$ & 5 & 2.7 \\
\hline & 。 & $25-50 \%$ & 28 & 17.6 \\
\hline & 。 & $<25 \%$ & 124 & 75.8 \\
\hline 21. & Do you & nsider that the cost of the vaccine is the main reason for its non- acceptance? & & \\
\hline & $\circ$ & Yes & 124 & 77.5 \\
\hline & 。 & No & 40 & 22.5 \\
\hline 22. & If vaccir & were cheaper, would you change your own opinion on it? & & \\
\hline & P & & 131 & 824 \\
\hline & $\stackrel{\circ}{\circ}$ & $\begin{array}{l}\text { Yes } \\
\text { No }\end{array}$ & $\begin{array}{l}131 \\
33\end{array}$ & $\begin{array}{l}0.4 \\
17.6\end{array}$ \\
\hline & Whom & you prescribe the vaccine?: & & \\
\hline & $\circ$ & Men & 1 & 0.7 \\
\hline & $\circ$ & Women & 108 & 72 \\
\hline & $\circ$ & Both & 41 & 27.3 \\
\hline & $\begin{array}{l}\text { Have yc } \\
\text { and } 26\end{array}$ & $\begin{array}{l}\text { recommended the vaccination to a family member or friend who is between } 11 \\
\text { ars old? }\end{array}$ & 92 & 58.2 \\
\hline & 。 & Yes & 72 & 41.8 \\
\hline & $\circ$ & No & & \\
\hline
\end{tabular}

Fig. 1 Survey 
Table 1 Socio-Demographic Data $(N=164)$

\begin{tabular}{ll}
\hline Women & $107(65.2)$ \\
Men & $57(34.8)$ \\
Mean age (years) & $46.6 \pm 9.2(23-64)$ \\
Proffesion : & \\
• PHCPs & $97(59.1)$ \\
• Nurse & $51(31.2)$ \\
• Pediatrician & $16(9.7)$ \\
Mean of years of professional experience (years) & $18.8 \pm 9.2(1-39)$ \\
Value in n(\%) or Mean \pm ST (Range) & \\
\hline
\end{tabular}

those who replied didn't know any of the genotypes against which both vaccines protect (Table 2 ).

Regarding the association between HPV infection and the development of cancer, $89 \%$ (146) of those who replied knew the relationship between HPV and cervical cancer. However, as reflected in Table 3, between 68 and the $80 \%$ of those who replied didn't know that the relationship between HPV and the other carcinomas in which it's involved.

Regarding the indications of the vaccine, $7.9 \%$ (13) answered that the highest priority age range of the vaccine is $9-14$. A total of $20(12.2 \%)$ didn't answer this question, and $80 \%$ (130) of those who answered have done so incorrectly.

Referring to the effectiveness of the vaccine (question 11), $65.45 \%$ (104) knew that the vaccine has proven to increase the amount of circulating antibodies and a decrease in the incidence of high-grade cervical lesions.

Table 2 Knowledge of genotypes included in the vaccine ( $N=164)$ Bivalent vaccine (Cervarix ${ }^{\circledR}$ contains VLPS of HPV 16 and 18)

- Knowledge of HPV 16

$1(0.61)$

- Knowledge of HPV 16 and 18

$62(37.8)$

- No knowledge of any of them

$101(61.6)$

Quadrivalent vaccine (Gardasil ${ }^{\circledR}$ contains VLPs OF HPV 16, 18, 11 y 6)

- Knowledge of all of them

$54(32.9)$

- No knowledge of any them

99(60.4)

- Knowledge of HPV 16 and 18

5 (3)

- Knowledge of HPV 11 and 18

$1(0.6)$

- Knowledge of HPV 6 and 18

- Knowledge of HPV 6, 11 and 18

$2(1.22)$

- Knowledge of HPV 11, 16 and 18

$2(1.22)$

Global knowledge

- Knowledge of every genotypes of both vaccine

46 (28)

- Knowledge of the genotypes of bivalent vaccine.

$16(9.7)$

- Knowledge of the genotypes of quadrivalent vaccine.

8 (4.8)

- No knowledge of any of the serotypes

Value in $\mathrm{n}(\%)$ or Mean \pm ST (Range))

However $17.6 \%$ (28) wrongly answered that the vaccine has been demonstrated to decrease the incidence of Ca. Cervix.

Most of those who answered (45.1\%) reported having obtained the information in medical journals, followed by training seminars (38.41\%) and by pharmaceutical representatives $(32.9 \%)$.

\section{Section III: Personal opinion about the vaccine and its inclusion in the immunization schedules}

The $71.3 \%$ (114) of participants consider that there is no consensus of opinion on the inclusion of the vaccine in the calendar among health professionals. Of these, $50 \%$ (54) considered that a majority agrees with its inclusion, $28.7 \%$ (31) considered a balance between the two positions and $21.3 \%$ (23) considered that a majority disagrees with its inclusion.

The $40.4 \%$ (65) of those who answered think that there is insufficient data to support the commercialization of the vaccine. The most frequent reason given $(65.7 \%)$ is that they think there is no data on long-term effectiveness.

The $59.6 \%$ (96) of the professionals vary on their opinion on the use of the vaccine in the public health system. The $32.3 \%$ of those who answered think that the coverage of the age range is insufficient.

\section{Section IV: Prescribing and recommending the vaccine}

According to the personal experience of the professionals, $75.8 \%(124)$ of them, consider $<25 \%$ the percentage of women between 15 and 50 years old that ask for information about the vaccine, $17.6 \%$ (28) consider this percentage to be around $25-50 \%, 2.6 \%$ (5) around $50-75 \%$ and $3.9 \%(7)$ in $\geq 75 \%$.

The $77.5 \%$ (124) of participants thinks that the number of patients who agree to be vaccinated would be higher if it were cheaper. However, $82.4 \%$ (131) did not change their own opinion despite decrease in price.

The $72 \%$ (108) of participants recommended the vaccine only to women and $27.3 \%$ (41) to both sexes; $59.8 \%(98)$ recommended the vaccine to the age range of $14-26,57.3 \%$ (94) to the age range of 11-14 years, and $15.2 \%$ (25) to the over 26. $58.2 \%$ (92) of participants recommended vaccination of their own family members aged between 11 and 26 .

When we analyzed the degree of recommendation of the vaccine based on proven knowledge about it (question 11) we notice that those professionals who correctly answered the question 11, recommend further vaccination (72.9 vs. $45 \%$; $p$-value 0.6$)$. The belief that the vaccine has been shown to decrease the incidence of cervical cancer also implies an increase in the percentage of professionals who recommend the vaccine (23.4 vs. $9.7 \%)$. 
Table 3 Comparison of professionals who support the vaccination vs. professionals who don't support the vaccination

\begin{tabular}{|c|c|c|c|c|}
\hline & & Support the & vaccination & \\
\hline & & Yes & No & $p$-value \\
\hline Correct answer & No & $32(45 \%)$ & 39 (54.9\%) & \\
\hline $\begin{array}{l}\text { to question II } \\
\text { (Effectiveness) }\end{array}$ & Yes & $62(72.9 \%)$ & $23(27 \%)$ & 0.696 \\
\hline Information from & No & $63(53.4 \%)$ & $55(46.6 \%)$ & \\
\hline congress & Yes & $33(76.8 \%)$ & $10(23.2 \%)$ & 0.008 \\
\hline Information from & No & $50(51 \%)$ & $48(49 \%)$ & \\
\hline & Yes & $46(73 \%)$ & $17(27 \%)$ & 0.006 \\
\hline To consider appropriate & No & $50(52.6 \%)$ & 45 (47.4 \%) & \\
\hline for vaccination & Yes & $46(71,8 \%)$ & $18(28.2 \%)$ & 0.015 \\
\hline
\end{tabular}

The recommendation of the vaccine is also influenced by the factors that could be used in marketing the professionals have considered to be the most influential. Those who think that the effectiveness and risk data are the most important factors, recommend the vaccine more (77.4 vs. $18.5 \%)$, while those who think that the commercial interests of pharmaceutical industry is the most important factor, recommended the vaccine to a lesser degree (11.8 vs. $56.9 \%$ ).

Professionals who have obtained information from conference attendance recommend to a greater extent the routine vaccination against those who have not attended courses and conferences (76.8 vs. $53.4 \%$; p-value $=0.008$ ). Likewise, those who have received the information from training seminars also recommend the routine vaccination more often (73 vs. $51 \%$; p-value 0.006 ).

\section{Discussion}

The clinical trials published have demonstrated an effectiveness of nearly $100 \%$ of both vaccines in women between 15 and 26 years old. Also, high immunogenicity in children under 15 years old has been demonstrated $[11,12]$. This has conditioned the modification of vaccination schedules in many countries.

Although the risk of HPV infection is higher at the beginning of sexual activity, it remains high throughout the sex life. Each year, 5-15\% of middle-aged women acquire a new infection $[13,14]$. On the other hand, the older the patient, the higher the probability of persistent infection and, therefore, increased risk of development cervical cancer. Several studies have confirmed the effectiveness of the quadrivalent vaccine in women until the age of 45 and the bivalent vaccine in women older than $26[15,16]$.

In Spain, the systematic vaccination against HPV was established in February 2007 for children between 11-14 years. Out of public funding, it was agreed to recommend vaccination for all women younger than 26 years and individualized assessment of vaccination to women over 26 years and in males 9-26 years. However, rates of vaccination in the population included in the public funding are lower than expected [8].

The vaccination rates are directly associated with the information provided to women on HPV infection and the characteristics of the vaccines [9]. The PHCPs are the first stage transmitting information and recommending the vaccine. The information given by professionals to the patients is conditioned by their own knowledge of the vaccines and their personal opinion on them.

In 2008, the Spanish scientific societies published a consensus document, based on the available evidence of the HPV vaccine, establishing the indications for the use of the vaccine. Three years later, in 2011, the impact of that document hadn't been as successful as it was to thought it should have been. Because of persistent doubts about the usefulness of the recommendations on vaccination against HPV, its effectiveness and risk [17] a new consensus document focused on HPV vaccination was published in 2011 [18].

In our study, we analyzed the knowledge of PCPs about HPV infection and the basic characteristics of the vaccines. The $89.2 \%$ of participants know the relationship between HPV and cervical cancer. However, it highlights their lack of Knowledge about genotypes included in the vaccines (57.3\% didn't know the serotypes against which both vaccines protect), and the relationship of HPV with cancer of the vagina, penis, vulva, oropharynx or anus (79.88, 73.78, 71.95, 70.12 and 68.29 \%).

One of the most important data obtained in our study is that $40.4 \%$ of participants think that there is insufficient data to support the commercialization of the vaccine. The main reason they consider $(65.7 \%)$ is there are no long-term studies on the influence of vaccination on mortality from cervical cancer. The $13.4 \%$ state that there are no studies of long-term risk of the vaccine, cost effectiveness $(10.4 \%)$, the possible need for revaccination (4.5\%) and the replacement of ecological niche for other HPV types (6\%).

Recently, Naud et al. have published their data of a longterm study with 9.4 years of follow-up in women vaccinated with Cervarix ${ }^{\circ}$. The effectiveness against CIN 2 was $100 \%$ and $100 \%$ of women remained seropositive against serotypes 16 and 18, with titers at least 10 times higher compared with natural immunity [19]. In addition, there are mathematical models that predict that the antibodies are to remain high for at least 20 years or even a lifetime [20].

Approximately 120 million doses of vaccine have been distributed worldwide. No serious adverse effects related to the vaccine have been observed in none of the clinical trials done [16, 18, 21]. The most frequently reported adverse effects were transient and at the part of the body where it was injected [22]. 
Regarding the cost effectiveness of the introduction of the vaccine as part of routine vaccination, the World Health Organization has established that HPV vaccination combined with a redesigned screening is the most effective strategy for the prevention of cervical cancer [23]. Castellsague et al. studied the impact of the vaccine in Spain with a mathematical model simulation. According to their conclusion with the combination of systematic vaccination in children, the stimulation of vaccination in young women outside public funding and the current screening programs, $83.5 \%$ of total costs associated with these diseases (168 million euros per year) would be reduced [24, 25].

On the other hand, note the perception of $75.8 \%$ of participants that less than $25 \%$ of women between 15 and 50 ask for the vaccine. This may be due to of a lack of information or knowledge within the general population about the implications of HPV infection, its causal association with cervical cancer and the importance of primary prevention. One of the causes for low immunization coverage in young adult women described in several epidemiological studies is the lack of awareness about the disease and concern about side effects of vaccination [26].

The main factor associated with the use of vaccine is the information that women have about the mechanism of HPV infection and its implication in several cancers and the effects of vaccination in terms of effectiveness and risk. It is important emphasize on the advantages of the systematic vaccination and individualization of each case in women over 14 [26].

The PHCPs are the first patient contact with the programs of primary and secondary prevention. The information that these professionals provide to their patients influences their decision-making. Therefore, such information must be based on the available scientific evidence.

Our study shows that there is a knowledge gap in primary health care professionals on basic aspects of HPV infection and its associated lesions, as well as the characteristics of vaccines and the population susceptible to receive it.

It is essential to ensure the training and continuous updating of professionals to provide dissemination of appropriate information to our patients and, consequently, facilitate and improve national HPV vaccine coverage.

\section{Conclusions}

The information given to patients about HPV, cancer and vaccine are the most important factors on vaccination (greater knowledge, greater acceptance). The knowledge and training of primary care professionals in this area should be enhanced, in order to improve the information given to our patients.

\section{Limitations of study}

Our results cannot be extrapolated to all PHCPs in Spain. Although the participation rate is acceptable and similar to those obtained by other authors such as Torné et al. [26] with a share of $40.4 \%$, or Mazzadi et al. [27] with a share of $15.23 \%$, it still remain a low percentage. It could be biased towards those professionals most motivated in participate.

\section{Abbreviations}

HPV: Human papilloma virus; PCPs: Primary care professionals; STD: Sexual transmitted disease; Cl: Confidence interval; VLPs: Native virus-like particles; GP: General practitioners; CIN: Cervical intraepithelial neoplasia; WHO: World Health Organization.

\section{Competing interests}

The authors declare that they have no competing interests

\section{Authors' contributions}

MRO: Conceived of the study, participated in its design and coordination, performed the statistical analysis and drafted the manuscript; $\mathrm{W}$ : Participated in the coordination of the study and helped to draft the manuscript; AVC: Participated in the design of the study, recruit data and helped to draft the manuscript; CR: Participated in the design of the study, recruit data and helped to draft the manuscript; SYC: Participated in the design of the study, recruit data and helped to draft the manuscript; LPC: Participated in the design of the study, recruit data and helped to draft the manuscript; JSJ: Participated in the coordination of the study and helped to draft the manuscript. All authors read and approved the final manuscript.

\section{Author details}

${ }^{1}$ Department of Gynecologic Oncology, Hospital Universitario 12 de Octubre, Avda Cordoba s/n, Madrid, Spain. ${ }^{2}$ Department of Obstetrics and Gynecology, School of Medicine, Complutense University, Madrid, Spain.

Received: 23 June 2015 Accepted: 23 September 2015

Published online: 16 November 2015

\section{References}

1. Castellsagué X, Iftner T, Roura E, Vidart JA, Kjaer SK, Bosch FX, et al. San Martin Rodriguez M, Serradell L, Torcel-Pagnon L, Cortes J;CLEOPATRE Spain Study GroupCLEOPATRE Spain Study Group. Prevalence and genotype distribution of human papillomavirus infection of the cervix in Spain: The CLEOPATRE Study. J Med Virol. 2012;84(6):947-56.

2. Muñoz N, Castellsagué X, de Gonzalez AB, Gissman L. Champter 1: HPV in the etiology of human cáncer. Vaccine. 2006;24 Suppl 3:S1-S10.

3. Alemany L, Pérez C, Tous S, Llombart-Bosch A, Lloveras B, Lerma E, et al. Spanish study group RIS HPV TT. Human papillomavirus genotype distribution in cervical cancer cases in Spain. Implications for prevention. Gynecol Oncol. 2012;124:512-51.

4. Castellsagué X, Cohet C, Puig-Tintoré LM, Acebes LO, Salinas J, San Martin $M$, et al. Epidemiology and cost of treatment of genital warts in Spain. Eur J Public Health. 2009;19:106-10.

5. Castellsague X, Garland SM. A review of clinical trials of human papillomavirus prophylactic vaccines. Vaccine. 2012;30 Suppl 5:F123-38.

6. De Sanjose S, Quint WG, Alemany L, Geraets DT, Klaustermeier JE, Lloveras B, et al. Retrospective International Survey and HPV Time Trends Study Group. Human papillomavirus genotype attribution in invasive cervical cancer: a retrospective cross-sectional worldwide study. Lancet Oncol. 2010;11(11):1048-56

7. Olsson SE, Villa LL, Costa RL, Petta CA, Andrade RP, Malm C, et al. Induction of immune memory following administrationof a prophylactic quadrivalent human papillomavirus (HPV) types 6/11/16/18 L1 virus-likeparticle (VLP) vaccine. Vaccine. 2007:25:4931-9.

8. Limia A, Pachón I. Coverage of human papillomavirus vaccination during the first year of its introduction in Spain. Euro Surveill 2011;16(21):pii $=19873$.

9. Black LL, Short MB, Sturm L, Rosenthal SL. Literature review of human papillomavirus vaccine acceptability among women over 26 years. Vaccine. 2009;27:1668-73 
10. Wu JP, Porch E, McWeeney M, Ohman-Strickland P, Levine JP. Knowledge and concerns related to the human papillomavirus vaccine among underserved Latina women. J Low Genit Tract Dis. 2010;14:155-61.

11. Dillner J, Kjaer SK, Wheeler CM, Sigurdsson K, Iversen OE, Hernández-Ávila $M$, et al. Four year efficacy of prophylactic human papillomavirus quadrivalent vaccine against low grade cervical, vulvar, and vaginal intraepithelial neoplasia and anogenital warts: randomised controlled trial. BMJ. 2010;341:c3493.

12. Wheeler CM, Castellagué X, Garland SM, Szarewski A, Paavonen J, Naud P, et al. Cross-protective efficacy of HPV-16/18 AS04- adjuvanted vaccine against cervical infection and precancer caused by non-vaccine oncogenic HPV types: 4-year end-of- study analysis of the randomised, double-blind PATRICIA trial. Lancet Oncol. 2012;13:100-10.

13. Muñoz N, Méndez F, Posso H, Molano M, Van den Brule AJ, Ronderos M, et al Incidence, duration, and determinants of cervical human papillomavirus infection in a cohort of Colombian women with normal cytological results. J Infect Dis. 2004;190(12):2077-87.

14. Sellors JW, Karwalajtys TL, Kaczorowski J, Mahony JB, Lytwyn A, Chong S, et al. Incidence, clearance and predictors of human papillomavirus infection in women. CMAJ. 2003;168(4):421-5.

15. Castellagué X, Muñoz N, Pitisuttithum P, Ferris D, Monsonego J, Ault K, et al, End-of-study safety, immunogenicity, and efficacy of quadrivalent HPV (types $6,11,16,18$ ) recombinant vaccine in adult women $24-45$ years of age. Br J Cancer. 2011;105(1):28-37.

16. Muñoz N, Manalastas Jr R, Pitisuttithum P, Tresukosol D, Monsonego J, Ault K, et al. Safety, immunogenicity, and efficacy of quadrivalent human papillomavirus (types $6,11,16,18$ ) recombinant vaccine in women aged 24-45 years: a randomised, double-blind trial. Lancet. 2009;373:1949-57.

17. Cortés J, Martinón-Torres F, Ramón y Cajal JM, Ferret G, Gil A. Considerations on the clinical application of the human papillomavirus vaccine in Spain. Hum Vaccines. 2011;7(5):585-9.

18. Cortés Bordoy J. Vaccination against the human papilloma virus. Consensus statement 2011 of the scientific Spanish societies. Semergen. 2012;38(5):312-26.

19. Naud PS, Roteli-Martins CM, De Carvalho NS, Teixeira JC, de Borba PC, Sanchez N, et al. Sustained efficacy, immunogenicity, and safety of the HPV-16/18 AS04-adjuvanted vaccine: final analysis of a long-term follow-up study up to 9.4 years post-vaccination. Hum Vaccin Immunother. 2014;10(8):2147-62.

20. David M-P, Van Herck K, Hardt K, Tibaldi F, Dubin G, Descamps D, et al. Long-term persistence of antiHPV-16 and -18 antibodies induced by vaccination with the AS04- adjuvanted cervical cancer vaccine: modelling of sustained antibody responses. Gynecol Oncol. 2009;115(Supple3):S1-6.

21. Chao C, Klein NP, Velicer CM, Sy LS, Slezak JM, Takhar H, et al. Surveillance of autoimmune conditions following rou- tine use of quadrivalent human papillomavirus vaccine. J Intern Med. 2012;271:193-203.

22. Agorastos T, Chatzigeorgiou K, Brotherton JM, Garland SM. Safety of human papillomavirus (HPV) vaccines: a review of the international experience so far. Vaccine. 2009;27:7270-81

23. Ginsberg GM, Edejer TT, Lauer JA, Sepulveda C. Screening, prevention and treatment of cervical cancer-A global and regional generalized cost-effectiveness analysis. Vaccine. 2009;27(43):6060-79.

24. Largerón N, Rémy V, Oyee J, San-Martín M, Cortés J, Olmos L. Análisis de coste- efectividad de la vacunación frente al virus del papiloma humano tipos 6, 11, 16 y 18 en España. Vacunas. 2008:9:3-11.

25. Castellsaué X, San Martín M, Cortés J, Gonzalez A, Remy V. Impacto de la vacuna tetravalente frente al virus del papiloma humano (VPH) tipos 6,11, 16 y 18 en las enfermedades asociadas al VPH en España. Prog Obsttet Ginecol. 2008;51:520-30.

26. Torné A, Bayas J, Castellsagué X, Castro M, García E, Martínez J. Vacunación frente al cáncer de cérvix en mujeres fuera de los programas de vacunación sistemática, con o sin infección por el virus del papiloma humano o lesión cervical. Encuesta de opinión y recomendaciones. Prog Obstet Ginecol. 2012;55:10-31.

27. Mazzadi A, Palomino M, Arrossi S. Aceptabilidad y conocimientos sobre la vacunación contra el virus del papiloma humano (VPH) en médicos ginecólogos de Argentina. Salud Pública Mex. 2012;54:515-22.

\section{Submit your next manuscript to BioMed Central and take full advantage of:}

- Convenient online submission

- Thorough peer review

- No space constraints or color figure charges

- Immediate publication on acceptance

- Inclusion in PubMed, CAS, Scopus and Google Scholar

- Research which is freely available for redistribution

Submit your manuscript at www.biomedcentral.com/submit 